\title{
Spatial distribution of multiple herbicide resistance in Echinochloa colona (L.) Link.
}

\author{
Diana Zabala $^{1 *}$, Nelson Carranza ${ }^{2}$, Aquiles Darghan ${ }^{1}$, and Guido Plaza ${ }^{1}$ \\ ${ }^{1}$ Universidad Nacional de Colombia, Facultad de Ciencias Agrarias, A.A. 14490, Bogotá, Colombia. \\ "Corresponding author (dmzabalap@gmail.com). \\ ${ }^{2}$ Dow Agrosciences de Colombia S.A.S., AA. 1001, Bogotá, Colombia.
}

Received: 3 May 2019; Accepted: 18 August 2019; doi:10.4067/S0718-58392019000400576

\begin{abstract}
Echinochloa colona (L.) Link is one of the most troublesome weed species in rice (Oryza sativa L.) crops. Despite numerous cases of herbicide resistance in E.colona worldwide, in Colombia the reports are scarce and most of them dating from over two decades ago. To screen the resistance of $E$. colona to bispyribac-sodium, cyhalofop-butyl and quinclorac, in the Saldaña and Purificación counties, a survey was carried out in 23 rice fields, through a grid of 26 squares of 2.56 $\mathrm{km}^{2}$ each. Seedlings from 23 populations were treated with commercial formulations from these respective herbicides at their recommended $(1 \mathrm{x})$ dose and twice the dose $(2 \mathrm{x})$ under controlled conditions. Relative fresh weight and percent control were evaluated. Populations with relative fresh weight greater than $20 \%$ and control below $80 \%$, were categorized as resistant. For statistical analysis, a mixed model was used with populations as a random effect. The distribution of resistance was evaluated by a spatial autocorrelation analysis. It was established that $91 \%$ of populations were resistant to bispyribac-sodium, $48 \%$ to cyhalofop-butyl and $43 \%$ to quinclorac. Sixty-five percent had multiple resistance to two herbicides and $22 \%$ to three herbicides. Resistance was randomly distributed, according to the results obtained from the mixed model that showed a homogeneous response of populations within fields and heterogeneous among fields. This indicates that management strategies at field level generate a local selection pressure that determines the evolution of the resistance independently in each field.
\end{abstract}

Key words: Cross-resistance, joint count analysis, junglerice, screening, mixed model, spatial autocorrelation.

\section{INTRODUCTION}

Herbicide resistance is the main problem in weed control around the globe and one of the greatest threats of modern agriculture. Accordingly, studies on herbicide resistance are at the forefront of current research in weed science (Neve et al., 2009; Panozzo et al., 2015a).

An early identification of the evolution of herbicide resistance in the field can help, if acted upon, to prevent, manage, mitigate and delay the spread of herbicide resistance (Burgos et al., 2013; Babineau et al., 2017), and in designing and implementing strategies to handle weed infestation (Panozzo et al., 2015a). An early identification of the evolution of herbicide resistance in the field can help, if acted upon, to prevent and delay the spread of resistance to neighboring weed populations.

The spatial scale on which herbicide resistant genes evolve is still poorly understood; in fact, the majority of studies on resistance only consider one or a few weed populations (Menchari et al., 2006; Schulz et al., 2014; Matzenbacher et al., 2015; Babineau et al., 2017). To handle new weed outbreaks that are resistant to herbicides, or invasive and harmful weeds, farmers need spatial information that describes the location and the propagation, within and across fields, of the problematic weeds (Cardina et al., 1997). Frequently updated and rapidly circulating maps of resistant biotypes are important in managing and tracing the evolution of herbicide resistance. Large scale maps that show the dissemination of 
the resistance at a continental and world level are already available in herbicide resistance global databases (Heap, 2019), nonetheless, more detailed maps are required at a national, regional and local level (Panozzo et al., 2015a).

The Echinochloa species are prone to developing resistance (Valverde et al., 2000). Echinochloa colona (L.) Link, is a hexaploid or tetraploid species (Yabuno, 1962), predominantly autogamous, which reproduces primarily through seeds but is able to reproduce through nodes (Masood et al., 2016). It is considered one of the most difficult grass weeds to control in summer and in vegetable crops in more than 60 countries (Masood et al., 2016). It is a dominant weed that is almost ubiquitous in rice crops (Valverde et al., 2000). High densities of E. colona have been reported in 24 countries with direct seeding rice crops, 12 with irrigated rice crops and in transplanted rice (Masood et al., 2016).

In rice crops, simple and multiple resistance to E. colona has been reported for the majority of modes of action (MOA), including photosystem II inhibitors (propanil), acetyl-CoA carboxylase (ACC) inhibitors (fenoxaprop, fluazifop, haloxyfop, cyhalofop-butyl), acetolactate synthase (ALS) inhibitors (penoxsulam, bispyribac-sodium, azimsulfuron, imazapyr, imazethapyr), 5-enolpyruvylshikimate-3-phosphate (EPSP) synthase inhibitors (glyphosate) and auxinic herbicides (quinclorac) (Heap, 2019). In Colombia, there are reports of resistance to propanil (Fischer et al., 1993), quinclorac (Valverde and Itoh, 2001) and penoxsulam in rice fields in Tolima (Carranza and Plaza, 2015).

Colombian farmers frequently encounter difficulties in controlling E. colona. Additionally, there is an overdependence of herbicides to control weeds and intensive planting of rice. These facts and the absence of scientific work focusing on resistance in Colombia suggest that there are unreported cases of herbicide resistance of E. colona.

The aforementioned aspects support the objectives of the current investigation: i) to determine the resistance of $E$. colona to the main post-emergent herbicides commonly used in rice crops, and ii) to map the spatial distribution of the resistance in the Saldaña and Purificación municipalities in Tolima.

\section{MATERIALS AND METHODS}

\section{Plant material}

In the second semester of 2016, we collected seeds from mature Echinochloa colona (L.) Link panicles in rice (Oryza sativa L.) fields nearing harvest. Each population was defined as the bulk of seeds collected in a single field. We collected 26 populations (labeled 42-67 - the labels number a larger set of populations). Each population was georeferenced and management condition, field history, weed management, and herbicides were recorded, through a structured interview. Additionally, two reference populations, previously characterized by Carranza and Plaza (2015), were also included: TA5 resistant to acetolactate synthase (ALS)- and acetyl-CoA carboxylase (ACC)-inhibitors herbicides and quinclorac, and VM susceptible to such herbicides. The seed of three of the collected populations $(44,54$ and 55$)$ did not germinate, so they were excluded from the study.

\section{Sampling the populations of Echinochloa colona}

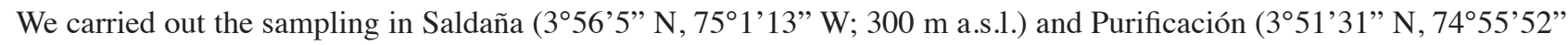
W; $310 \mathrm{~m}$ a.s.1.) municipalities in Tolima state (approximate area $66.56 \mathrm{~km}^{2}$ ). We used a grid of 26 squares, each of 2.56 $\mathrm{km}^{2}$, to guarantee at least one square for every thousand cultivated hectares (22000 ha at the time of sampling). The grid was designed using the geographic information system (GIS) ArcGIS 10.4.1 trial program (Environmental Systems Research Institute [ESRI], Redlands, California, USA), spatial analysis tools and images captured by the LandSat8 satellite operated by the United States Geological Survey (USGS; Reston, Virginia, USA). In each square, we chose a rice field at random, and in this field, we collected seeds using simple random sampling. Subsequently, seeds were stored at $4{ }^{\circ} \mathrm{C}$ for 3-mo.

\section{Experimental design}

The evaluation to the response of herbicides was carried out under controlled conditions, in a completely randomized design, with a complete factorial arrangement of three replicates. The first factor were the $E$. colona populations, along with the reference populations: susceptible (VM) and resistant (TA5). The second factor were the herbicides. Three herbicides were evaluated in three doses: bispyribac-sodium (sodium 2,6-bis((4,6-dimethoxypyrimidin-2-yl)oxy) benzoate; Army $400 \mathrm{SC}$, Adama Andina, Barranquilla, Colombia) at 0, 50 and $100 \mathrm{~g} \mathrm{ha}^{-1}$; cyhalofop-butyl (butyl (2R)-2- 
[4-(4-cyano-2-fluorophenoxy)phenoxy]propanoate; Clincher EC, Dow AgroSciences, Indianapolis, Indiana, USA) at 0, 270 and $540 \mathrm{~g} \mathrm{ha}^{-1}$; and quinclorac (3,7-dichloroquinoline-8-carboxylic acid; Facet SC, BASF, Ludwigshafen, Germany) at 0,375 and $750 \mathrm{~g} \mathrm{ha}^{-1}$. The selected dose for each herbicide corresponded to $1 \mathrm{x}$ and $2 \mathrm{x}$ the commercial dosage. The experimental unit was a pot with 10 plants. To check out our results, the experiment was done twice.

The seeds were scarified with $10 \% \mathrm{HCl}$ for $20 \mathrm{~min}$, after that they were placed in Petri dishes with $0.6 \%$ agar (w/v), $0.2 \% \mathrm{KNO}_{3}$ and $32 \mu \mathrm{g} \mathrm{mL}^{-1}$ ampicillin. When the seedlings emitted the first leaf, they were transplanted to soil in pots of dimensions $10 \times 7 \times 8.5 \mathrm{~cm}$. Herbicides were applied when the plants displayed three fully extended leaves. Spraying was done using a $\mathrm{CO}_{2}$ at a constant pressure of $33 \mathrm{kPa}$ with a Tee Jeet 8002 nozzle and an application volume of $200 \mathrm{~L}$ $\mathrm{ha}^{-1}$. Fourteen days after the treatment (dat) we evaluated fresh weight (g) and performed visual control (in contrast to the plants not treated with herbicide).

\section{Statistical analysis}

For the statistical analysis, variables were normalized using the following transformations: square root (bispyribacsodium and cyhalofop-butyl) and logarithmic (quinclorac) for fresh weight, and arcsine for the control. Using the lme function of the nlme package with R Project (Pinheiro et al., 2017), we selected a linear mixed model using restricted maximum likelihood to analyze the three variables. We evaluated the inclusion of the populations as a random effect, as well as the interaction of the populations with the environment (experiments 1 and 2) and the replicates. The herbicide dose was included as a fixed effect in the model. In order to further evaluate the explanatory power of the model, we used a log-likelihood ratio test (Pinheiro et al., 2017), which is calculated as 2 [log-likelihood of model B - $\log$-likelihood of model A], where model A is more general than model B (model A has fewer random effects). The resulting distribution can be approximated as a chi-squared distribution with degrees of freedom $\mathrm{K}_{\mathrm{B}}-\mathrm{K}_{\mathrm{A}}$, where $\mathrm{K}_{\mathrm{i}}$ is the number of parameters model i would predict (Pinheiro et al., 2017). We selected the simplest model, which resulted in significant results in the log-likelihood ratio test and the lowest values for the Akaike information criterion (AIC), and the Bayesian information criterion (BIC) (Aho et al., 2014). Subsequently, we compared the response of the variables (transformed) to the fixed effects, for different treatments, using the glht function of the multcomp package in R (Hothorn et al., 2008). Finally, for analyzing the results, average values obtained for each variable and each herbicide was using the original units.

\section{Screening for resistance herbicides and spatial distribution}

In order to categorize a population as herbicide resistant, we adapted the criterion of Panozzo et al. $(2013 ; 2015 b)$ in the following way:

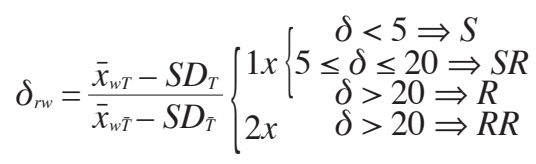

where, $\delta_{r w}$ is relative fresh weight delta; $\bar{x}_{w T}$ is average fresh weight of treated plants; $S D_{T}$ is standard deviation fresh weight of treated plants; $S D_{\bar{T}}^{-}$is standard deviation fresh weight of untreated plants.

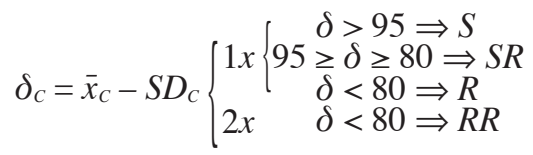

where $\delta_{r w}$ is visual control delta; $\delta_{c}$ is visual control delta; $\bar{x}_{w}$ is average visual control of treated plants; SD is standard deviation visual control of treated plants.

$\mathrm{S}$ and SR categories were considered as susceptible and R and RR categories as resistant. When the categories were different within the populations according to the evaluated variable, the category obtained with the relative fresh weight was selected.

For each herbicide, the resistance categorization was represented spatially with the help of thematic cartography, using the ArcGIS 10.4.1 trial program, spatial analysis tools and images captured by the LandSat8 satellite operated by USGS. In order to establish if there was correlation between geographic location of the populations (field) and resistance, we computed spatial autocorrelation using a join-count analysis in the program $R$ ( $R$ Core Team, 2014), assigning a value of 1 to resistant populations (R and RR) and 0 to susceptible populations (S and SR). 


\section{RESULTS AND DISCUSSION}

The areas of the fields varied between 4 and 30 ha. In general, little information was obtained from herbicide applications. Of the information collected, $69 \%$ routinely used propanil, $46 \%$ bispyribac-sodium and $54 \%$ quinclorac. Specifically with the use of quinclorac and cyhalofop, it was established that their main use was in late post-emergence (beginning of flowering of E. colona) and in E. colona patches with low controls of previous applications. In addition, it was established that bispyribac-sodium is routinely used in each harvest cycle ( 2.3 cycles $\mathrm{yr}^{-1}$ in this area), with doses even 4 times higher than the commercial dose.

The mixed model that displayed the best fit, for each variable and each herbicide, is described in Table 1. It should be noted that general response to the herbicides (fixed effect) varied across populations (random effect) and was consistent among replicates (due to lack of interaction between populations and replicates). When the experiments were repeated after months, the response varied (random effect), but the variation was nonsignificant (due to the absence of interaction between fixed effects and environment; data not shown).

Bispyribac-sodium (Figure 1) did not diminish biomass accumulation (5\%) and in fact, the response was similar even upon doubling the dose $(\mathrm{p} \geq 0.05)$. The control increased by $12 \%$ upon doubling the dose $(\mathrm{p} \leq 0.05)$. For cyhalofop-butyl and quinclorac the response varied with dosage ( $\mathrm{p} \leq 0.05$ ). According to categorization of resistance (Table 2), $91 \%$ of populations were resistant ( $\mathrm{R}$ and $\mathrm{RR}$ ) to bispyribac-sodium, $48 \%$ to cyhalofop-butyl, and $43 \%$ to quinclorac (Figure 2). Additionally, we observed that $96 \%$ of populations became resistant to at least one herbicide (74\% with 2x dosage), $65 \%$ to two (13\% with $2 \mathrm{x}$ dosage) and $22 \%$ to three herbicides ( $0 \%$ with 2x dosage) (Table 2). The spatial autocorrelation analysis revealed that the resistance to all three herbicides had a random spatial distribution, and consequently there are not noticeable aggregation patterns on the maps (Figure 3).

Management problems with propanil-resistant E. colona in the 1980s led to the widespread use of bispyribac-sodium in Colombia (Valverde, 2007). In addition to the overuse of this herbicide encountered during sampling, in other research was established that bispyribac-sodium is the herbicide most used in the late post-emergency (Ramírez and Plaza, 2015). It is very likely that the strong selection pressure lead to the results we saw (91\% of populations resistant). Additionally, and despite the fact that farmers in Colombia have a long history of difficulty managing E. colona with ALS-inhibitors, it was only in 2015 that Carranza and Plaza (2015) reported outbreaks of E. colona resistant to penoxsulam in rice fields of Tolima. These facts, along with the established history of using ALS-inhibitors in this area and our finding that the TA5 (resistant to penoxsulam) was also resistant to bispyribac-sodium suggest possible cases of crossed resistance, which still await verification.

Another alternative for the management of propanil-resistant E. colona were ACCase-inhibitors, mainly fenoxaprop, which with the subsequent selection of biotypes resistant to this herbicide, made way for an alternative herbicides such as cyhalofop-butyl (Valverde, 2007). In fact, bispyribac-sodium, propanil, and cyhalofop-butyl are herbicides frequently used in post-emergence in that area (Ramírez and Plaza, 2015). Cyhalofop-butyl was more effective at controlling weeds than bispyribac-sodium in the populations we studied (36\% more for $1 \mathrm{x}, 49 \%$ more for $2 \mathrm{x}$ ). Despite this, using the commercial dose, $48 \%$ of populations were resistant, doubling the dose only $9 \%$ of the populations remained resistant (RR). In other words, the problems in managing E. colona with cyhalofop-butyl, were overcome when the dosage was doubled. Both herbicides, ALS-inhibitor and ACCase-inhibitor, pose a high risk in the evolution of herbicide resistance

Table 1. Explanatory power and importance of the random effects in the mixed linear models selected for each variable with the bispyribac-sodium, cyhalofop-butyl and quinclorac herbicides.

\begin{tabular}{|c|c|c|c|c|c|c|c|c|c|c|}
\hline Variable & Fixed effect & $\mathrm{P}$ & $\mathrm{P} \times \mathrm{E}$ & $\mathrm{P} \times \mathrm{R}$ & Loglik & AIC & BIC & PRV & df & $\mathrm{p}$-value \\
\hline \multirow[t]{3}{*}{ Control } & Bispyribac & $\mathrm{x}$ & $\mathrm{x}$ & - & -501.08 & 1014.16 & 1037.63 & 27.53 & 6 & $<0.0001$ \\
\hline & Cyhalofop & $\mathrm{x}$ & $\mathrm{x}$ & - & -554.08 & 1120.16 & 1143.82 & 11.36 & 6 & 0.001 \\
\hline & Quinclorac & $\mathrm{x}$ & $\mathrm{x}$ & - & -420.95 & 853.91 & 876.70 & 22.57 & 6 & $<0.0001$ \\
\hline \multirow[t]{3}{*}{ Weight } & Bispyribac & $\mathrm{x}$ & $\mathrm{x}$ & - & -18.50 & 49.00 & 72.46 & 12.07 & 6 & 0.0005 \\
\hline & Cyhalofop & $\mathrm{x}$ & $\mathrm{x}$ & - & 60.59 & -109.17 & -85.52 & 7.15 & 6 & 0.0075 \\
\hline & Quinclorac & $\mathrm{x}$ & $\mathrm{x}$ & - & 172.69 & -333.39 & -310.54 & 32.11 & 6 & $<0.0001$ \\
\hline
\end{tabular}

x: Random effects adjusted in the selected model; P: populations; E: experiments; R: replicate; Loglik: logarithmic likelihood tests; AIC: Akaike information criterion; BIC: Bayesian information criterion; PRV: likelihood ratio test; df: degrees of freedom; p-value: significance between the models, based on Loglik. 
Figure 1. Fresh weight and percentage of control of 23 populations of Echinochloa colona in response to bispyribacsodium, cyhalofop-butyl and quinclorac.
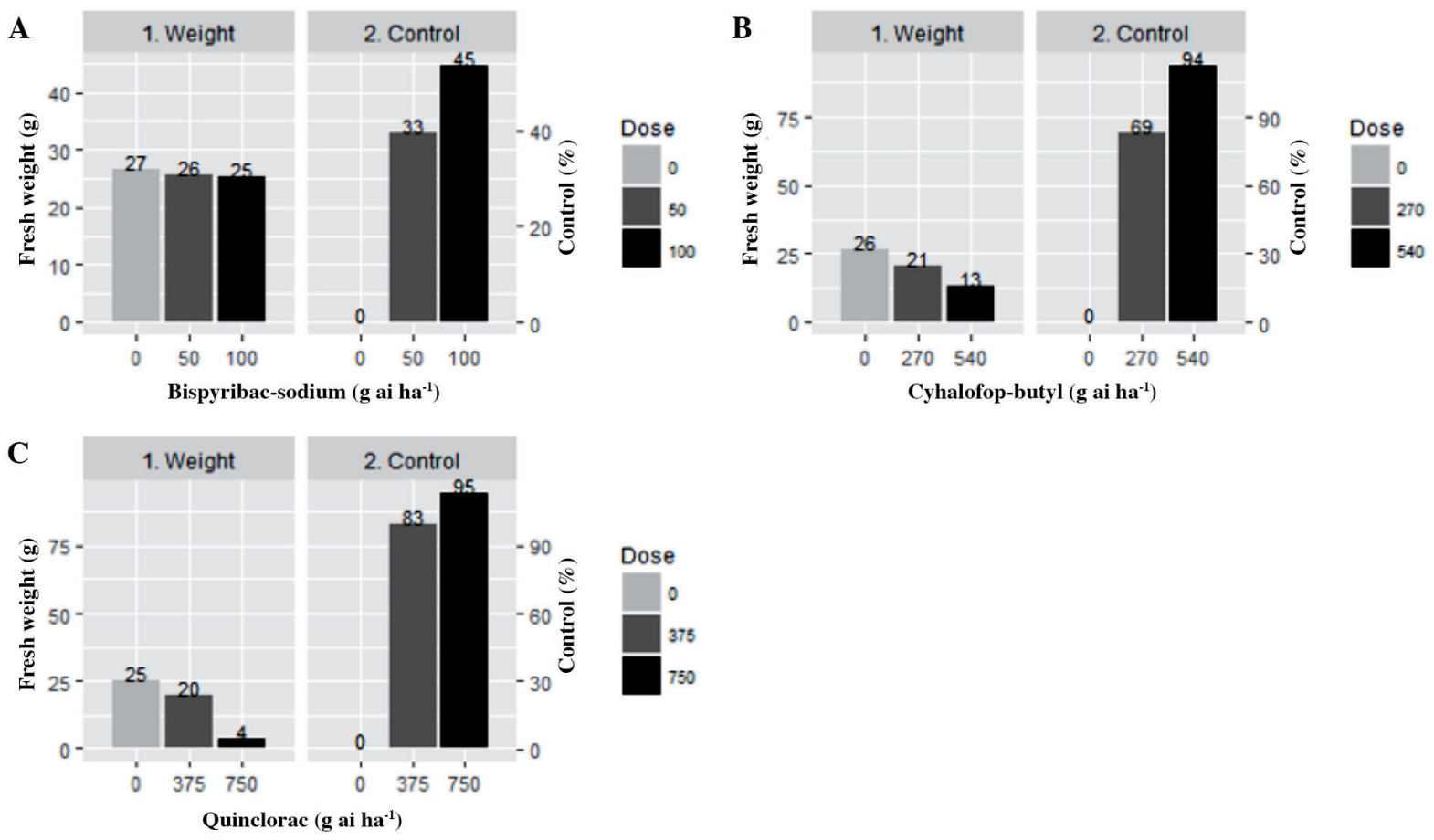

A) Bispyribac-sodium at 0,50 and $100 \mathrm{~g} \mathrm{ha}^{-1}$, B) cyhalofop-butyl at 0,270 and $540 \mathrm{~g} \mathrm{ha}^{-1}$ and C) quinclorac at 0,375 and $750 \mathrm{~g}$ ha $^{-1}$. Variables: fresh weight and control.

The average values are presented in the upper part of the bar, and in the lower part the significance of the comparison tests (different letters are significantly different, $\mathrm{p} \leq 0.05$ ).

(Valverde et al., 2000). In fact, applying a mixture of penoxsulam and cyhalofop-butyl, in E. crus-galli has been shown correlation with the selection of multiple resistance to these herbicides (Chen et al., 2016). The differences that we found when doubling the dose are due to historical selection pressure (changes in the use of cyhalofop-butyl when bispyribacsodium entered the market; Valverde, 2007). Additionally, during the sampling process we found that unlike bispyribacsodium, farmers do not use cyhalofop-butyl in all the crop cycles and when they do use it, they apply it in the late stages of post-emergence.

The results with quinclorac were very similar to those of cyhalofop-butyl. This contrast with the difficulty that farmers report from the fields when they try to manage E. colona with quinclorac, whose application in the studied area is usually done in the last phase of post-emergence. Even though the product label does not specify the ideal moment to apply the herbicide during post-emergence, these results show that the use of the herbicide in the phase of three to four leaves could help diminish the difficulty of managing this weed species in the sampled fields.

Ten years after the introduction of quinclorac, O. Schmidt (2000 BASF, Germany), in personal communication with Valverde and Itoh (2001), reported quinclorac resistance in Colombia for the first time. The sole other study was that of Carranza and Plaza (2015), where 60\% of the accessions were resistant. In our work, the percentage of quincloracresistant populations was $43 \%$, but upon doubling the dose, only $9 \%$ were resistant (RR), meaning that similarly to cyhalofop-butyl, doubling the dose diminished the difficulty of managing E. colona. Even though these results suggest that increasing dose would be a good strategy to overcome the hardship in controlling E. colona, such an approach would also increase the selection pressure and would thus induce a more rapid evolution of the resistance to these herbicides. Cultural management to reduce the settlement, impact and fertility of these weeds in the crops should be the primary tool.

As far as the spatial distribution of the resistance is concerned, this was random for the three herbicides (there was no apparent pattern of aggregation). In other works on grass weeds resistant to ALS- and/or ACCase-inhibitor herbicides, which tried to establish some kind of correlation between geographic location and resistance, the results have been similar 
Table 2. Categorization of the resistance of 23 populations from Echinochloa colona to bispyribac-sodium, cyhalofop-butyl and quinclorac.

\begin{tabular}{|c|c|c|c|}
\hline Population & Bispyribac & Cyhalofop & Quinclorac \\
\hline 42 & $\mathrm{RR}$ & $\mathrm{R}$ & SR \\
\hline 43 & $\mathrm{RR}$ & $S$ & SR \\
\hline 45 & R & $\mathrm{RR}$ & R \\
\hline 46 & RR & $\mathrm{RR}$ & SR \\
\hline 47 & $\mathrm{RR}$ & SR & SR \\
\hline 48 & SR & SR & $\mathrm{R}$ \\
\hline 49 & $R R$ & $\mathrm{~s}$ & SR \\
\hline 50 & $\mathrm{RR}$ & $S$ & $S$ \\
\hline 51 & $\mathrm{RR}$ & R & $\mathrm{RR}$ \\
\hline 52 & RR & $\mathrm{R}$ & SR \\
\hline 55 & $\mathrm{SR}$ & SR & S \\
\hline 56 & $\mathrm{RR}$ & $S$ & $S$ \\
\hline 57 & $\mathrm{R}$ & SR & $\mathrm{R}$ \\
\hline 58 & RR & R & RR \\
\hline 59 & $\mathrm{R}$ & $\mathrm{R}$ & $\mathrm{R}$ \\
\hline 60 & RR & $\mathrm{R}$ & $S$ \\
\hline 61 & RR & $S$ & $\mathrm{R}$ \\
\hline 62 & $\mathrm{RR}$ & $\mathrm{R}$ & $\mathrm{R}$ \\
\hline 63 & RR & R & SR \\
\hline 64 & $\mathrm{RR}$ & SR & $\mathrm{R}$ \\
\hline 65 & RR & SR & SR \\
\hline 66 & $\mathrm{R}$ & SR & $\mathrm{R}$ \\
\hline 67 & $\mathrm{RR}$ & R & $S$ \\
\hline TA5 & $\mathrm{RR}$ & $\mathrm{R}$ & $\mathrm{R}$ \\
\hline VM & $S$ & $S$ & $S$ \\
\hline
\end{tabular}

$\mathrm{R}:>1 \mathrm{x}$ (recommended dose) resistant; RR: > resistant to $1 \mathrm{x}$ and $2 \mathrm{x}$ (twice the recommended dose); S: $>95 \%$ susceptible with 1x; SR: $>80 \%-95 \%$ susceptible with $1 \mathrm{x}$; light gray: > resistance to an herbicide; medium gray: $>$ resistance to two herbicides; dark gray: > resistance to three herbicides.

(Menchari et al., 2006; Schulz et al., 2014; Babineau et al., 2017). There have even been studies on the frequency of genes that confer resistance to ACCse in Alopecurus myosuroides, but they failed in detecting spatial structure in the distribution at all geographic scales (Menchari et al., 2006). Kuester et al. (2015) agree that resistance evolved independently in each field, meaning that control of the species is more successful if done at the level of each field.

These results agree with those obtained through mixed model analysis, where introducing populations as random effects resulted in a response to herbicides that was differential across populations but homogeneous in each population. In other words, individuals in each field we sampled showed homogeneity in their response to treatments, but across fields, their responses were heterogeneous.

The selection pressure herbicides exercise locally, can explain the homogeneity of the populations at the level of each field. Due to, herbicide spraying programs are designed at the level of a field that create a mosaic of local selective pressures (Menchari et al., 2006; Délye et al., 2010). Additionally, when resistant genes are introduced into a field by pollen migration or resistant seeds from near-by fields (Busi et al., 2011), they most likely arrive repeatedly from different directions. Thus, spatial distribution of resistant plants in a field are expected to be patchy during a few generations from its introduction (Jasieniuk and Maxwell, 1994). Nybom (2004) found that for annual, autogamous plants that have gravity-dispersed seeds or tend to adhere to animals, a smaller genetic variance is expected intra-populationally, while 
Figure 2. Frequency of resistance of 23 populations of Echinochloa colona to, bispyribac-sodium, cyhalofop-butyl and quinclorac.
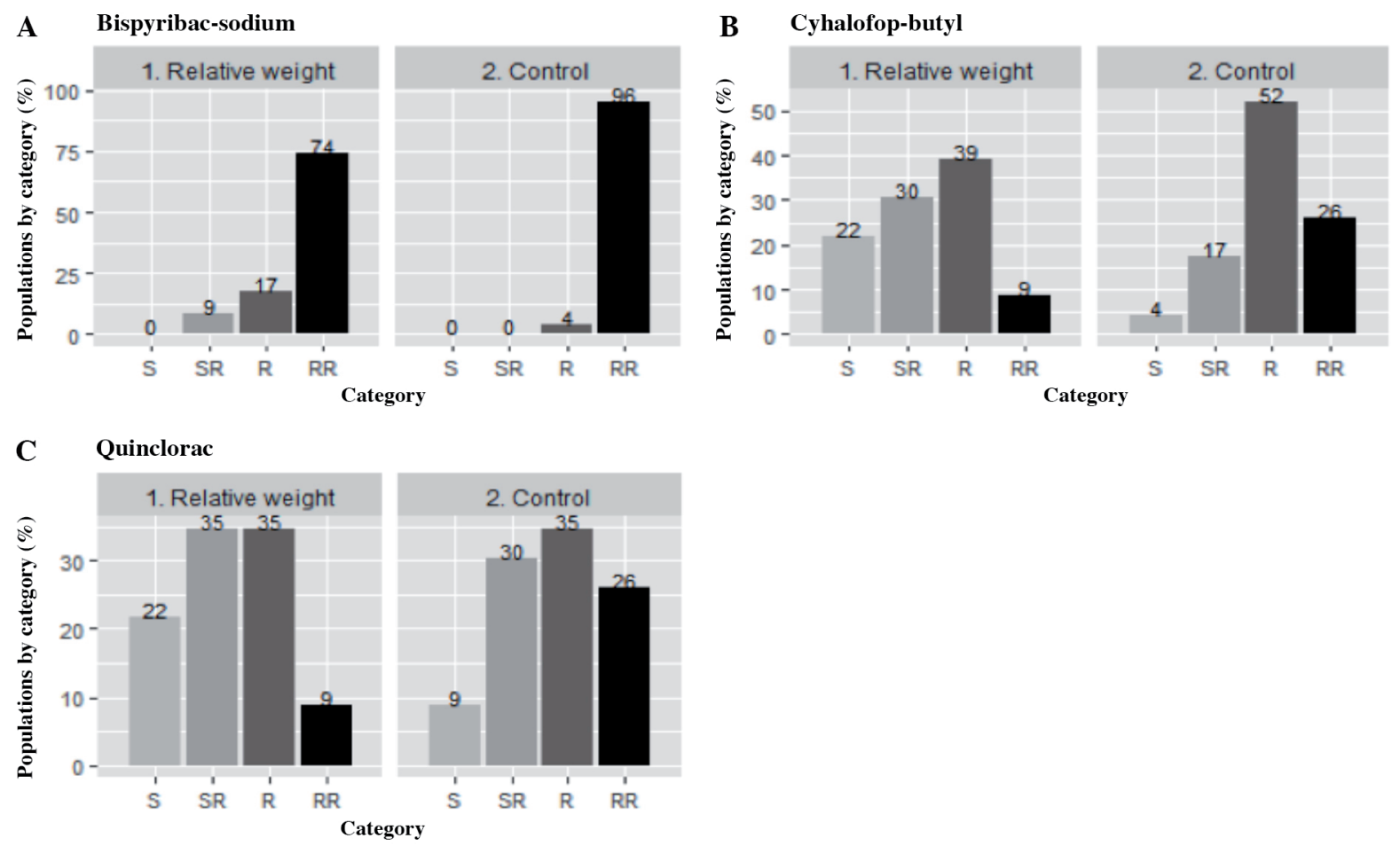

A) Bispyribac-sodium, B) cyhalofop-butyl and C) quinclorac, calculated from relative fresh weight and control. Categories: resistant ( $\mathrm{R}$ and $\mathrm{RR}$ ) and susceptible (S and $\mathrm{SR})$.

inter-populationally this variance is likely higher. Echinochloa colona, being an annual and predominantly autogamous plant, is also awnless (Masood et al., 2016), which diminishes its mobility inside the field. In agreement with these aforementioned characteristics, the homogeneity among populations inside a field and heterogeneity across fields can be due to both selection pressure and to the biology of the species.

As far as the dispersion of the resistance is concerned, we must contemplate the ways in which resistant genes can propagate. In Costa Rica, Rojas and Agüero (1996) found that E. colona thrives in irrigation canals, dispersing seeds in the water and re-infecting commercial rice fields. The Saldaña and Purificación municipalities have been able to rely on irrigation water supplies from the Usosaldaña irrigation district during the last five decades, which could have favored the spreading of resistant seeds in the area. However, it is known that seeds can also be spread through the displacement of dirty agricultural machinery, the use of contaminated seeds, or by adhering to skin, feathers, animal paws and human clothing (Masood et al., 2016). During the sampling process, we observed that many agricultural activities were carried out by groups of persons and machinery operators that work in different fields, which would imply an anthropic dispersion of seeds in addition to that evidently achieved through irrigation.

On the other hand, we can establish that the timing of the experiments (3-mo gap between replicates) affected the response of the plants to the herbicides, as there was environmental variation between the two trials. The ability of groups of individuals present in the sampled populations to produce more than a single phenotype when exposed to environmental variation is consistent with the definition of phenotypic plasticity (Kelly et al., 2012). Nonetheless, the interaction between environment (experiments) and dose of herbicide (fixed effects) was nonsignificant; this means that the plastic response was not present in all the populations.

Starting from what we found with categorizing herbicide resistance and determining its spatial distribution, we argue that it is important to conduct any mitigation work at the level, of a single field or group of fields. Simple procedures such as cleaning machinery, clean crop seed, weed seed removal at harvest and seed destruction post-harvest, could help to decrease dissemination of seeds across fields (Busi et al., 2011), causing difficulty in the spreading of the resistance. Neve et al. (2009) signal the need to manage weeds using a broad perspective that takes into account the evolutionary biology of 
Figure 3. Distribution map of the resistance of 23 populations of Echinochloa colona to bispyribac-sodium, cyhalofopbutyl and quinclorac.
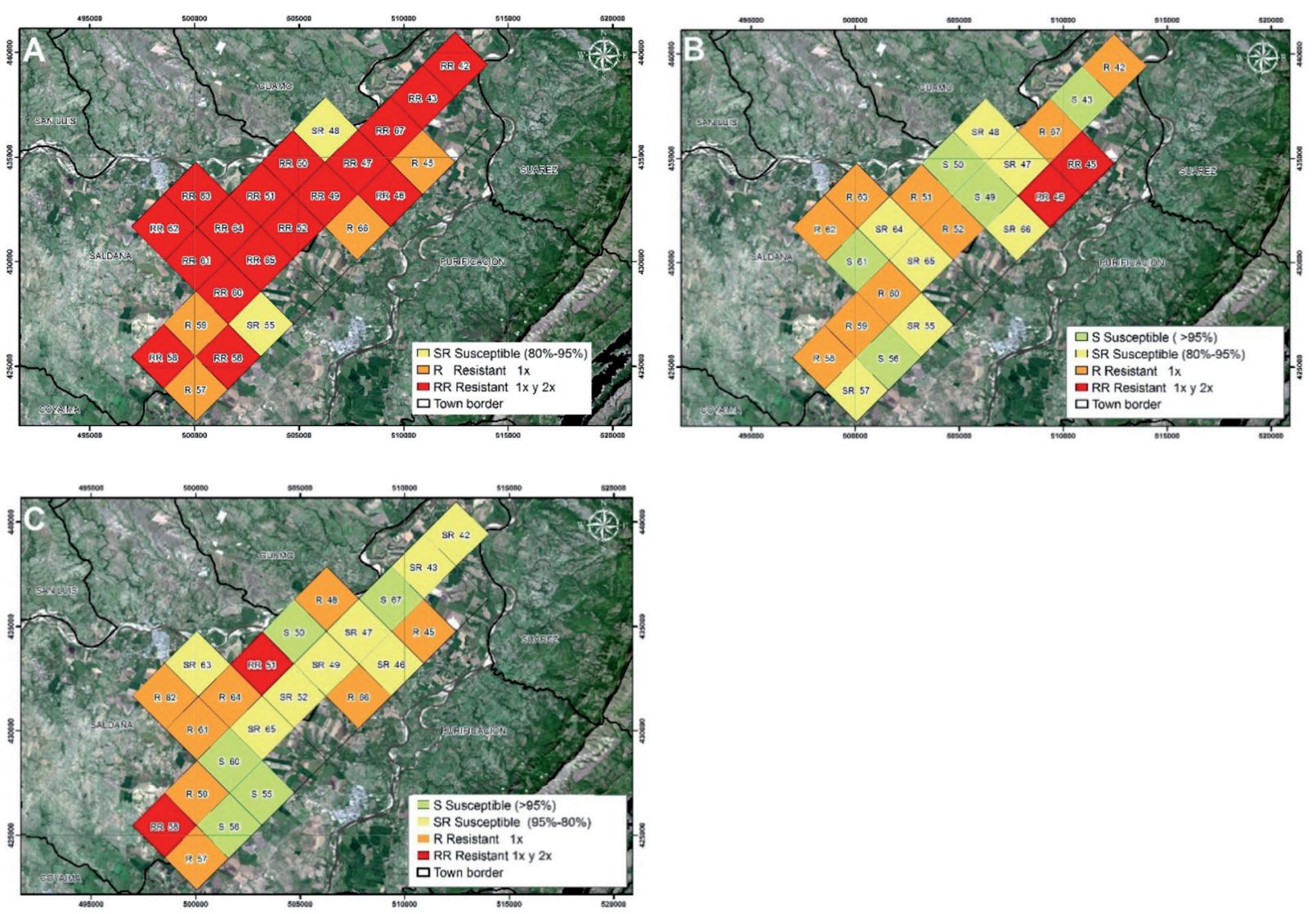

A) Bispyribac-sodium (recommended dose [1x] $50 \mathrm{~g} \mathrm{ha}^{-1}$; twice recommended dose [2x] $100 \mathrm{~g} \mathrm{ha}^{-1}$ ), B) cyhalofop-butyl (1x: $\left.270 \mathrm{~g} \mathrm{ha}^{-1} ; 2 \mathrm{x}: 540 \mathrm{~g} \mathrm{ha}^{-1}\right)$ and C) quinclorac $\left(1 \mathrm{x}: 270 \mathrm{~g} \mathrm{ha}^{-1} ; 2 \mathrm{x}: 540 \mathrm{~g} \mathrm{ha}^{-1}\right)($ Scale 1:125 000).

the plant species, achieving prevention or at least minimizing its adaptation and propagation. In this sense, these authors show the importance of a deep knowledge on the extent, structure and significance of the genetic variation inside and across weed populations. The use of mixed effects in this work allowed us to model variation among individuals, intraand inter-populationally. Nonetheless, additional work is required in order to define this variation at a genetic level.

\section{CONCLUSIONS}

Through this study, we documented herbicide resistance of Echinochloa colona in Colombian rice crops. We detected E. colona populations that were resistant to bispyribac-sodium (91\%), cyhalofop-butyl (57\%) and quinclorac (52\%). In the case of cyhalofop-butyl and quinclorac, the percentage of resistant populations decreased upon doubling the dose of herbicide ( $13 \%$ and $17 \%$, respectively). Ninety six percent of populations were resistant to at least one herbicide, and we detected multiple resistance to two (65\%) and three (22\%) herbicides. The spatial distribution of the resistance was random.

The inclusion of the mixed model in analysis enabled us to evaluate the response to the herbicides without allowing the natural variability of the populations to interfere with the results. This approach demonstrated that population responses were homogeneous inside the same field, heterogeneous across fields, and varied as a function of environment.

We conclude that the interaction between weed management and crop and biology of E. colona dictate the evolution of herbicide resistance at the level of a single field, and thus resistance management of this species of weed must be done at this scale too. 


\section{ACKNOWLEDGEMENTS}

This research was funded by Dow Agrosciences de Colombia SAS. The authors thank Luis Reinoso (Dow Agrosciences de Colombia SAS) for his support in the sampling of the seeds and execution of greenhouse tests. We thank Bernal Valverde and Teresa Mosquera for their review and helpful comments on earlier drafts of the manuscript.

\section{REFERENCES}

Aho, K., Derryberry, D., and Peterson, T. 2014. Model selection for ecologists: the worldviews of AIC and BIC. Ecology 95(3):631-636.

Babineau, M., Mathiassen, S.K., Kristensen, M., Holst, N., Beffa, R., and Kudsk, P. 2017. Spatial distribution of acetolactate synthase resistance mechanisms in neighboring populations of silky windgrass (Apera spica-venti). Weed Science 65(4):479-490.

Burgos, N.R., Tranel, P.J., Streibig, J.C., Davis, V.M., Shaner, D., Norsworthy, J.K., et al. 2013. Review: confirmation of resistance to herbicides and evaluation of resistance levels. Weed Science 61(1):4-20.

Busi, R., Michel, S., Powles, S.B., and Délye, C. 2011. Gene flow increases the initial frequency of herbicide resistance alleles in unselected Lolium rigidum populations. Agriculture, Ecosystems and Environment 142:403-409.

Cardina, J., Johnson, G.A., and Sparrow, D.H. 1997. The nature and consequence of weed spatial distribution. Weed Science 45(3):364-373.

Carranza, N., y Plaza, G. 2015. Resistencia de Echinochloa colona a penoxsulam y otros herbicidas inhibidores de la acetolactato sintetasa (ALS) en campos de arroz (Oryza sativa) de Colombia. Abstract 572-575. In XXII Congreso Latinoamericano de Malezas, Buenos Aires. 9-10 September. Asociación Argentina de Ciencia de las Malezas (ASACIM), Buenos Aires, Argentina.

Chen, G., Wang, Q., Yao, Z., Zhu, L., and Dong, L. 2016. Penoxsulam-resistant barnyardgrass (Echinochloa crus-galli) in rice fields in China. Weed Biology and Management 16(1):16-23.

Délye, C., Clément, J.A.J., Pernin, F., Chauvel, B., and Le Corre, V. 2010. High gene flow promotes the genetic homogeneity of arable weed populations at the landscape level. Basic and Applied Ecology 11:504-512.

Fischer, A.J., Granados, E., and Trujillo, D. 1993. Propanil resistance in populations of junglerice (Echinochloa colona) in Colombia rice fields. Weed Science 41(2):201-206.

Heap, I. 2019. The international survey of herbicide resistant weeds. Available at http://www.weedscience.org (accessed 10 January 2019).

Hothorn, T., Bretz, F., and Westfall, P. 2008. Simultaneous inference in general parametric models. Biometrical Journal 50(3):343-363.

Jasieniuk, M., and Maxwell, B.D. 1994. Populations genetics and the evolution of herbicide resistance in weeds. Phytoprotection 75(4):25-35.

Kelly, S.A., Panhuis, T.M., and Stoehr, A.M. 2012. Phenotypic plasticity: molecular mechanisms and adaptive significance. Comprehensive Physiology 2:1417-1439.

Kuester, A., Chang, S-M., and Baucom, R.S. 2015. The geographic mosaic of herbicide resistance evolution in the common morning glory, Ipomoea purpurea: Evidence for resistance hotspots and low genetic differentiation across the landscape. Evolutionary Applications 8:821-833.

Masood, A., Ahsan, A., and Singh, B. 2016. Biology, impact, and management of Echinochloa colona (L.) Link. Crop Protection 83:56-66.

Matzenbacher, F.O., Bortoly, E.D., Kalsing,A., and Merotto, A. 2015. Distribution and analysis of the mechanisms of resistance of barnyardgrass (Echinochloa crus-galli) to imidazolinone and quinclorac herbicides. Journal of Agricultural Science 153:1044-1058.

Menchari, Y., Camilleri, C., Michel, S., Brunel, D., Dessaint, F., Corre, V.L., et al. 2006. Weed response to herbicides: regionalscale distribution of herbicide resistance alleles in the grass weed Alopecurus myosuroides. New Phytologist 171:861-874.

Neve, P., Vila-Aiub, M., and Roux, F. 2009. Evolutionary-thinking in agricultural weed management. New Phytologist 184(4):783-793.

Nybom, H. 2004. Comparison of different nuclear DNA markers for estimating intraspecific genetic diversity in plants. Molecular Ecology 13:1143-1155.

Panozzo, S., Colauzzi, M., Scarabel, L., Collavo, A., Rosan, V., and Sattin, M. 2015a. iMAR: an interactive web-based application for mapping herbicide resistant weeds. PLOS ONE 10(8):e0135328.

Panozzo, S., Scarabel, L., Collavo, A., and Sattin, M. 2015b. Protocols for robust herbicide resistance testing in different weed species. Journal of Visualized Experiments 101:e52923.

Panozzo, S., Scarabel, L., Tranel, P., and Sattin, M. 2013. Target-site resistance to ALS inhibitors in the polyploid species Echinochloa crus-galli. Pesticide Biochemistry and Physiology 105(2):93-101. 
Pinheiro, J., Bates, D., DebRoy, S., Sarkar, D., and Team R Core. 2017. nlme: linear and nonlinear mixed effects models. R package version 3.1-141. https://CRAN.R-project.org/package=nlme.

R Core Team. 2014. R: A language and environment for statistical computing. R Foundation for Statistical Computing, Vienna, Austria. Available at http://www.r-project.org (accessed June 2018).

Ramírez, J.G., and Plaza, G. 2015. Effect of post-emergence herbicide applications on rice crop weed communities in Tolima, Colombia. Planta Daninha 33(3):499-508.

Rojas, M., y Agüero, R. 1996. Malezas asociadas a canales de riego y terrenos colindantes de arroz anegado en finca El Cerrito, Guancaste, Costa Rica. Agronomía Mesoamericana 7(1):9-19.

Schulz, A., Mathiassen, S.K., and De Mol, F. 2014. Approaches to early detection of herbicide resistance in Apera spica-venti regarding intra- and inter-field situations. Journal of Plant Diseases and Protection 121(3):138-148.

Valverde, B.E. 2007. Status and management of grass-weed herbicide resistance in Latin America. Weed Technology 21(2):310-323.

Valverde, B.E., and Itoh, K. 2001. World rice and herbicide resistance. p. 203-301. In Powles S.B., and Shaner, D.L. (eds.) Herbicide resistance and world grains. CRC Press LLC, Boca Ratón, Florida, USA

Valverde, B.E., Riches, C.R., y Caseley, J.C. (eds.) 2000. Prevención y manejo de malezas resistentes a herbicidas en arroz: experiencias en América Central con Echinochloa colona. Cámara de Insumos Agropecuarios, San José, Costa Rica.

Yabuno, T. 1962. Cytotaxonomic studies on the two cultivated species and the wild relatives in the genus Echinochloa. Cytologia 27(3):296-305 